\title{
Philosophical Foundations for Democracy: A Ukrainian Perspective
}

\author{
Anatoliy Tolstoukhov
}

Charity Organization "Center for Practical Philosophy" Frolivska Str. 1/6, 04070 Kiev, Ukraine; tel. (0038044)-238-65-23. sofi@kiev.farlep.net

\section{Yuriy Myelkov}

Charity Organization "Center for Practical Philosophy" Frolivska Str. 1/6, 04070 Kiev, Ukraine; tel. (0038044)-238-65-19. yurimelkov@univ.kiev.ua

\begin{abstract}
The article intends to conduct a philosophical analysis of democracy as it is presented by democratization processes in societies under globalization. The turbulent political life of contemporary Ukraine with its 'revolution' of 2004 provides an excellent example of such a process. The authors demonstrate that processes in question could be denoted as rather manipulation than democratic transition. Democracy today finds its subject not in the modern nation-state, but in human personalities engaged in social self-organization and opposed to crowds led by contemporary demagogues.
\end{abstract}

Keywords: Democracy, democratization in Ukraine, personality, 'Orange revolution', social self-organization

$\mathrm{T}$ he aim of this article is to conduct a philosophical investigation of the nature of democratic processes in contemporary society. Ukrainian society that has faced many political events in recent years is an adequate source of inspiration for our philosophical musing over its experience. However, we still intend to review democracy in its essence, in its universal notion applicable to the whole contemporary world, rather than focus our attention on empirical representations of a democratic system in Ukraine or in any other country. Indeed, those representations could be considered rather doubtful and/or incomplete. Our position would probably raise even more doubts and generate some distrust - regarding not democracy itself, but conscious or unconscious usurpers of that name engaged in hiding unattractive features of manipulation technologies under the mask of democracy.

\section{Democracy: philosophy and nonlinear approach}

Democracy is now one of the most common terms used in the public rhetoric; however, it seldom serves as an object of philosophical reflection. Indeed, democracy could sometimes appear as a 'worn out' notion used in order to express quite different feelings and ideas. The situation with democracy in post-communist countries in fact resembles their recent past. The usage of the word 'democracy' equals to the usage of the word 'communism' several decades ago: the term is widely used on official occasions, but nobody takes it for real. And the fact that many today's born democrats in Ukraine and other ex-Soviet republics are former convinced communists only strengthens the idea that 'democracy' could be perceived as a keyword denoting the belonging of its bearer to the self-described 'power party'. As 
Ukrainian sociologist Iryna Popova explains that situation:

"...parading the 'democracy' of our
society, constant usage of the term
'democracy' in the situation of
lawlessness and actual violation of
people's rights, considerable spreading
of poorness and poverty is a blasphemy,
because it leads to devaluation of that
word, to the commonplace perception of
democracy as a situation where
'anything goes', and 'a plain man' has no
protection against that. In other words,
against a background of our practices,
that terms obtains the sense, which is
directly opposite to what a researcher
means by it" (Popova, 2008, pp. 19-20).

Nevertheless, we still believe that the phenomenon of democracy should not be reduced to its real-political connotation and must be studied by means of philosophy, providing foundations for its true realization. However, such studies require an adequate approach based, in particular, on contemporary paradigm of nonlinearity, selforganization, and concreteness. What we mean by such a statement is that there are at least two major conception of democracy: political and philosophical, - democracy as a certain given way of organizing the political system (that features general elections, parliament, freedom of speech etc.), and democracy as a certain ideal of harmonious social life (democracy from a philosophical, rather than political, perspective).

Our position here is close to the tradition of participatory democracy. In particular, its illustrious American champion Benjamin Barber (1984) argues that the two types of democracy present in today's society are official democracy with its 'Big politics', party intrigues, corruption and bureaucracy, - and real 'neighborhood democracy' with its practice of local self-government and grassroots voluntary activities. That's why, according to Barber, we have to expand our understanding of what counts as democratic, rather than expanding democracy itself. However we think that the philosophical approach to democracy is aimed at limiting that understanding rather than expanding it for every philosophical term implies strict limitations over phenomena of reality that fit (or do not fit) the notion. That is, democracy by definition must be separated from other phenomena that exist in our society and title themselves as a democracy while not satisfying all the necessary requirements for such a denotation.

So, how then should philosophy understand the term 'democracy'? Democracy as just 'power of the people' as it is usually being explained, as the people's sovereignty, where the people are the sources, the bearers, and the conductors of power, - such a formulation used to present an adequate guideline and an ideal of social-political structure at the age of Absolutism, when the usual reality was the dominance of a sole monarch or a narrow circle of persons possessing power by the right of birth. Then the ideal of the power for all the people - and not one single person or single exclusive estate - was progressive and revolutionary.

But today such an approach to understanding and defining democracy turns out to be very abstract - that is, not clear enough in order to serve as a lodestar in the semidarkness of the political life of our society, which already calls itself 'democratic'. As Barber (1984) states, the history of democracy itself is contained in the history of the word democracy. In our opinion, that history lies in the concretization of the notions people ('סńноs') and power ('кра́тоร') that constitute the term 'democracy'. Such a concretization could still be presented as a development (not only expansion) of the meaning of the notions in question. In Ancient times, the democracy of poleis was based on the labor of masses of slaves, deprived of any rights, even of the right to be considered as human beings. The 'סńnos' (people who can be and are subjects of democracy) quite differs here from ' $\lambda$ aós' (all the people in general, saying nothing of their possibility to be subjects of power). In other words, 'the people' here are certainly not all the people we often have in mind when we talk about true democracy. Medieval European cities, which also had some form of democracy, supplied obstacles of similar kind as well. Until the end of the $18^{\text {th }} \mathrm{C}$., strict qualifications based on property or social status prevented all the people from participating in political life, 
let alone their ability to become subjects of power.

However, even after all the revolutions of $18^{\text {th }}, 19^{\text {th }}$, and $20^{\text {th }}$ centuries, it could not be testified that humanity in any way has really achieved true democracy, when all the people participate in policy making in full. Still, the development of the human society and its government could be presented as an evolution towards the most optimal form of that society and that government, that is, towards democracy. In other words, democracy under such nonlinear approach appears not as a given state of affairs, but as a constant process of development. Neither stage of that process could be considered as a complete democracy in fact, but each one of those stages can serve as a certain approximation to that ideal - the complete realization of democratic form of social and political organization of human life.

The notion of the people who can be and are subjects of social and political power is being constantly specified and extended. Gradually, the slaves, the serfs, the workers, the poor, women, national minorities and other groups and strata are tending to be included into the notion of 'demos', into the volume of people subject to be bearers and conductors of social power. Thus, national democracy discovers that different ethnic groups have equal rights for participation in the life of society. Similarly, social democracy defends rights of the poor, and stands for equality of all human beings irrelevant to their social positions.

Those named forms of democracy, - or, it would be better to say, those stages of the democratization process, - are still actual under present-day situations. However, at the same time, they remain abstract in relation to further possible concretization of what democracy really is. Both social and national 'democracies' appear as obsolete under the situation of the globalizing world. Globalization changes human lives, their traditional modes of activity, and requires even more specification of both our ideals and forms of our social organization. The world is now more unified than ever, and its common future that concerns every person could be easily endangered with a simple single action by a superpower. We think that such a situation conditions the necessity for all people of the world to decide directly, and not through their representatives of any kind, the fate of humanity.

That means that the notion of power present in the term 'democracy' also develops and concretizes itself. In Greek, as well as in other languages, there are different nuances of the word 'power'. First, it is the initial 'кра́тоs', power as a wraparound dominance and possession, peculiar to the past historical forms of total governance. Second, it is a more gentile 'ópxos' - power as a guidance and administration. And finally, it is ' $\varepsilon \xi o u \sigma i ́ a '-$ power as the ability to create, to behave, to act. While all three do contribute to our understanding of democracy, the development from the first to the second and then to the third of denoted aspects could be seen as the real process of democratization (see: Tolstoukhov, Myelkov, \& Parapan, 2008).

Unfortunately, the situation we now observe is quite different, if not opposite, from what philosophy can and should say about democracy. Democracy in its most widespread meaning is considered not as a process of social evolution, but - in a linear perspective - as a certain given state of affairs that exists in some time and place and could be easily transferred to other time and place. Most western experts do believe that only the 'Westminster' model of democracy, especially in its American version, with all its traditional attributes - like legal state, strict division of power, parliamentarianism, and civil society - is the only possible form of democracy. Thus, any deviation from that model in any country, any insufficient level of the development of some of its elements, or their absence at all, is branded as an inadequacy and/or incompleteness of democracy in that country.

Such a view does not give justice to contemporary nonlinear studies of democracy we are trying to conduct, neither to its classical ideal representations. We would like to cite the criticism of that position by famous Canadian theoretician of participatory democracy, C. B. Macpherson: 
"The model of democracy that has been raised to orthodoxy in American political science... is counter-democratic (by the older concept of democracy) in that it empties out, as being normative, unrealistic, or utopian, the egalitarian and developmental moral ideal of the original liberal-democratic theory, and accepts as an adequate model (and proclaims as the only accurate model) of democracy, a competition between two or more élite groups for the power to govern the whole society. Democracy is held to be consistent with, and even to require, a low level of citizen participation: only so, it is said, is the political system likely to stay in equilibrium. Democracy is reduced from a humanist aspiration to a market equilibrium system. And although the new orthodox theory claims scientific neutrality, its value judgment is clear enough: whatever works, is right - that is, whatever enables the existing classstratified society to operate without intolerable friction is best" (Macpherson, 1973, pp. 78-79).

In other words, without the people acting as real subjects of democracy, the democracy itself turns to be just euphemism, and the use of this term for denoting the said model becomes philosophically and scientifically unjustified. Democracy as a historical concept is inseparable from the Modern classical way of thinking, classical humanism, and the idea of general liberation of a human being from the dictate of tradition and authority. Democracy is such a state where every person, using Kant's expression, has the courage to use one's own mind. In this case using one's own mind while governing oneself and one's society, and not trying to alienate that burden and that privilege in favor of somebody else.

The 'élite theory' could state that all the people do not have such a developed state of mind so that they could really exercise the mentioned courage and ability, and it is thus obvious that a circle of 'people's representatives' must be elected to govern the society. However, in our opinion, even if such state of affairs is considered to be temporary or preliminary, while providing for the gradual process of transition towards 'total and pure' democracy (like in Lenin's 'vanguard' theory), there is still one problem remained. Particularly, the ability to use one's own mind is required for electing adequate political representatives to the bodies of representative democracy, no less then it is needed for actual self-governance under the situation of conceptual 'complete democracy'. We can sum the presuppositions for representative democracy considered as a lawful embodiment of classical democratic theory as the following - a person that has no possibility to conduct his/her power over social governance directly, comprehends and accepts:

- his/her democratic right for exercising the power;

- his/her inability to actually realize that power, either because of shortage of time, or deficiency of personal qualities or education;

- his/her interests in such a governance that could be delegated to another person;

- that person's suitability for governing the society in accordance with the elector's interests.

It could be easily concluded then that requirements for the true democratic elector are in no way less utopian then those that define the true democratic subject of power.

So, it turns out that the theory of representative democracy from the philosophical point of view, in its contemporary form, has little to do with rational classical democracy (Myelkov, 2007). There is no rational possibility for an elector to choose an adequate delegate. Political scientists, like Samuel Popkin (1994), find it appropriate to talk about 'low information rationality', 'gut reasoning' etc, when élite politics are being chosen basing on emotional criteria. Still, as the indicated author has to admit, "There is something rather miraculous about the fact that citizens believe that leaders selected by balloting are legitimate, that they are entitled to govern" (Popkin, 1994, p. 8).

Thus, the realization of the true democracy is inseparable from philosophical consideration of democracy as a process of 
development. It is not enough for democracy to provide human with an abstract right to govern his or her social and political system. The very nature and features of that system should enable human to be capable of governing it. Democracy that only provides rights to the people, and does not care about realizing those rights, is but a mere formality. For example, western system supplies both the rich and the poor with equal rights; at the same time it does not take into account that their real positions are quite different. 'Equal opportunities' do not always mean 'equal possibilities'. That rule would certainly not work in non-western countries, like Ukraine. It would only lead to corruption and further social misbalance of power that in no way could be described as a kind of democracy or even a step towards democracy.

To be more precise, the definition of democracy as the system where each human being is the bearer and the conductor of power, implies that each human being is indeed the highest value of democracy, and not those structures and institutions that constitute the corresponding system of political and social power in society, even if they belong to the long-standing traditions of Western Democracies. That is, democracy is not the division of power, neither is it parliamentarianism or elections of representatives. Democracy is just means for optimizing social life so that it would better suit interests of each person. In other case, the struggle for democratization of the world turns to be moral relativism. Democracy is not 'Democracy above all', but 'Each person above all'. Violent implantation of 'western standards' as the only criterion of legitimate democratization is anti-democratic in fact. The ideal of the power of the people is essentially concrete. We can call any country a democracy if and only if it has democratic idea realized in the best way possible under concrete conditions of its embodiment, while the given level of democratic governance corresponds to social-economical abilities and cultural-political features of the society.

\section{Ukrainian 'revolution' of 2004: democracy vs. manipulation}

The authors of this article feel that they have the right to muse about philosophy of democracy in the way they do that in the previous chapter, because events in Ukraine in 2004 that somehow gained the semiacknowledged title of 'the Orange revolution' form an excellent empirical basis for reviewing the democratization processes under globalization. While analyzing that 'revolution', we prefer to rely on our own experience as its forced observers, and on independent sources published in Ukraine (Pohrebinskiy, 2005; Pohrebinskiy \& Tolpygo, 2007). In Europe or the US, public opinion concerning the 'Orange revolution' was shaped by other points of view, though, and those positions often misrepresent the events happened in 2004 (see, for example: Kuzio, 2005).

In short, the 'myth of the Orange revolution' goes as follows: under Presidential elections in Ukraine in 2004, there was a competition between 'authoritarian' 'power' candidate Yanukovich, and 'popular', 'pro-democratic' candidate Yushchenko. The second round proved victory to Yanukovich (with $49 \%$ to $46 \%$ ), but many significant falsifications were revealed, people entered streets demanding fair elections and democracy, and the third round of elections, organized by the order of Supreme Court, finally claimed victory for Yushchenko.

We would now state our objections to that myth. First, revolution means radical change of the whole social system. Such change is comprehensive and fundamental; it takes years to be fulfilled and centuries to be comprehended. We are still not ready to summarize the results of the Great French revolution of the $18^{\text {th }} \mathrm{c}$., to say nothing of those of socialist revolutions of the $20^{\text {th }} \mathrm{C}$. As for events of the beginning of the $21^{\text {st }} \mathrm{c}$., 'Orange', 'Rose' and other so-called revolutions are not worthy to bear that honorary title. A real revolution can hardly coincide with elections conducted in accordance with the lawful constitution, as it mysteriously happened in Ukraine. The social system had not been changed as a result of those events; the only change that had taken place is the change of élites in power. In no 
way Yushchenko and his prominent supporters represented a popular opposition to the corrupted system of power ('regime of Kuchma', the former Ukrainian President): there were two former prime ministers, two former Parliament speakers, and a number of former ministers among leaders of the Orange revolution'. And the replacement of élites in power is what one would usually call 'coup d'état', and not revolution. The claims of the victorious party for the status of revolution leaders naturally originate some doubts as for the very fact of their democratic election, to say nothing of the legality of its results.

The election process transformed into welldirected performance, where the masses were assigned a part of a flash mob, can hardly be described as a popular democracy. Colin Crouch, British author of the 'postdemocracy' conception, writes:

"Under this model, while elections
certainly exist and can change
governments, public electoral debate is a
tightly controlled spectacle, managed by
rival teams of professionals expert in the
techniques of persuasion, and
considering a small range of issues
selected by those teams. The mass of
citizens plays a passive, quiescent, even
apathetic part, responding only to the
signals given them. Behind this
spectacle of the electoral game, politics
is really shaped in private by interaction
between elected governments and élites
that overwhelmingly represent business
interests" (Crouch, 2004, p. 4).

Second, one more important characteristic of any social revolution is that revolution is indeed some form of self-organization, as the people rise to defend their rights and interests, and thus it appears as a big leap towards democracy. True revolution is indeed carried out by masses, and not only by a group of revolutionaries, although the latter often provides a necessary condition for forming premises for national revolutionary uprising. However, the masses that had found themselves standing on Maidan and shouting 'Yushchenko for President' were rather organized than self-organized - for a presidential campaign is by no means a spontaneous process. Prominent Ukrainian politician Evheniy Kushnaryov, who opposed Yushchenko, describes his experience of visiting the Maidan:

"I asked my driver to try to get to the Maidan. Upon return, he said that the guards did not let him pass. They questioned him for a long time, who is he, from where, why did he come. They contacted a foreman by radio, which questioned him again, and finally told that they won't let him pass to the Maidan without a clear answer on who is he and whom does he represent... It is clear... What is going on the Maidan - is not a spontaneous action, but an organized process with its own ideology and precise inner structure" (Kushnaryov, 2005, p. 23).

That is, under such a 'revolution', it is not masses of the people that self-organize themselves into democratic movement. It is rather certain politicians that organize revolts of crowds to support their claim for the place at the top of the government. Simple as that. A crowd does not consist of developed and conscious personalities, and thus it is eager to obey demagogues and to drive its destructive force into any direction pointed by them. Revolutions are not created by crowds; crowds as a destructive tool in hands of external leaders, and the people, the consolidated communities composed of creative personalities, - those are two quite different things. As Russian philosopher Mikhail Lifshitz says:

"The people create the great rallying of the revolution, while a crowd supervised by demagogues decomposes and ruins it. Movements similar to fascism transform the people into a crowd; movements similar to the October revolution raise a crowd onto the level of the people" (Lifshitz, 1988, p. 235).

That is, instead of developing human personalities, non-democratic revolts depend on unconscious destructive force of organized crowds. Coming back to the Orange revolution', we note that the leaders of crowds had been prepared beforehand to direct that spontaneous force. The result is not selforganizing democratic revolution - that 
revolution is just a false front for a complex of what is called political technology: a series of non-democratic ways of gaining power by manipulating human consciousness. As French journalist Vincent Jauvert observes, 'creators of revolutions' are being hand-picked and prepared in western centers for overthrowing social systems of the East:

"In general they are employed by western institutions, mostly Americans. They can be named international democratic brigades' controlled by Washington. Some of them have been consecrated into 'champions of freedom' by George Bush himself. For overthrowing regimes of the East, those revolutionaries have unique know-how, subtle mixture of non-violence, marketing and fund raising" (Jauvert, 2005, p. 3).

Thus, we come to another important feature of 'the Orange revolution'. Recent events in Eastern Europe are nothing but an 'export of democracy' from the West. Instead of supporting democracy as the self-organization of the Ukrainian society, leaders of the Orange revolution relied solely on external ideological forces. They were naturally opposed by 'easterners' that relied rather on Russia than on the West. But both positions here present an extrapolation of internal contradiction of the Ukrainian society. Instead of being developed in a dialectical way and creative collaboration of different positions (what true democracy is, we believe), political leaders transformed that contradiction into the reason for revolts of crowds. Those events serve interests of the USA government, interests of some or other political leaders, but not interests of the civil society and the citizens of Ukraine. The most regrettable observation we have to make is that it was the USA competing with Russia during Ukrainian 2004 elections, and not really democratization

\footnotetext{
1 "Et en général ils sont employés par des institutions occidentales, principalement américaines. A leur sujet, on pourrait parler de «brigades internationales démocratiques", parrainées par Washington. Certains d'entre eux ont d'ailleurs été sacrés «champions of freedom» par George Bush en personne. Pour renverser les despotes de l'Est, ces révolutionnaires ont un savoirfaire unique, subtil mélange de non-violence, de marketing et de fund raising (collecte de fonds)".
}

processes peculiar to the Ukrainian society itself.

It is obvious that the practice of relying on external forces in the struggle for power and even in the development of a certain society could not be described as a feature of democracy. The legitimacy power of Western authorities was strict and unambiguous: USA had officially stated that they are not accepting the results of the Ukrainian elections, if the pro-western candidate is not declared the winner (Richter, 2004)! But you cannot force the people into freedom and democracy - that's the one lesson we, the people of the former USSR, have learnt from our former communist experience. And it is quite bitter to see similar mistakes made by contemporary 'democrats', trying to achieve that abstract democracy by concrete antidemocratic actions, like overthrowing and threatening the legitimate political system elected by a democratic process.

Of course, the kind of 'democracy' forced and introduced by 'the Orange revolution' does not reflect the will of the whole population, but only that of one part of it. Supposing, as the careful analysis suggests, that there were falsifications made by both sides on almost equal scale (see: Pohrebinskiy, 2005), one has to assume that the Ukrainian society became highly polarized during elections, and resolving the crisis would have been required a very cautious approach. However, 'a revolution' here refers to the minority usurping the power: Yushchenko turns out to be 'the President of Maidan', and not the President of Ukraine.

Ukrainian situation since 2004 proves that statement. After its victory, the Orange power has virtually deprived the other part of society its right to exist, its right to express its opinion. About half of Ukrainian citizens, mostly located in the East or in the South regions of Ukraine, were at once proclaimed 'bandits' and 'reactionaries'. Only 'Orange' ideology became legitimate, and only Orange identity was openly allowed. For example, there was a criminal case initiated against the cited politician, Evheniy Kushnaryov, who said during 'the revolution' that in his Kharkov region there would be no 'Donetsk power' or 
'Lvov power', but only 'Kharkov power'. That seemingly rational notion was considered as 'separatism' and 'federalism' and prosecuted by the new Orange central government (Kushnaryov, 2005). It is not surprising then that already in 2005 the sharp decrease of trust the people had for their Orange leaders was registered (Pohrebinskiy \& Tolpygo, 2007); and permanent squabbles within the Orange democrats' have deprived them of the confidence bonus they had received from Europe and the US by 2009.

\section{Human Personality as the New Subject of Democracy}

In our opinion, the experience of 'the Orange revolution' provides but another incentive for philosophical rethinking of democracy, for constructing a new ideal of the democratization process, based on non-linear approach, as described in the first chapter of this article. The first reason for that is the inadequacy of the Modern conception of nation-state under the situation of the globalized world. In fact, it is the task of nation-building that drives Yushchenko and other Orange leaders along the course of abstract linearity, imposing unitary identity on Ukrainian citizens. And struggle for the dominant administrative power within the nation-state no longer serves as an example of democracy, and not only in Ukraine. But the irony of Ukraine's history (and that of other newly independent countries) lies in its certain backwardness: their sovereignty could appear as a doomed one while being established in times of globalization.

Humanity today is challenged with a transition to the next form of the democratic social system - the third one, after its antique and medieval polis form, and its nation-state modern form, - the system encompassing humanity as a whole. There is a criticism about nation-state, postulating its irrelevance and uselessness in our times, appearing both from the left and from the right. We can just mention two books with the identical title "The end of the nation state" - published in

\footnotetext{
2 These cities are informal capitals of Eastern and Western Ukraine, and in 2004 they were major support centers for correspondingly Yanukovich and Yushchenko.
}

1995 (Ohmae, 1995; Guéhenno, 1995). The authors come to similar conclusions while sharing quite opposite positions and different premises.

Japanese business-consultant Kenichi Ohmae, who is an avid supporter of the economical globalization and free market system, argues that nation-states lack any meaning for global economy: they hamper the development of the economy with their barriers and social programs; traditional nation states now become "unnatural, even impossible business units in a global economy" (Ohmae, 1995, p. 5). The new subjects of humankind development are 'economical regions' that overcome any national borders - and Ohmae here abstracts away from any cultural, traditional, and human-related issues.

French diplomat Jean-Marie Guéhenno (the original French title of his above-mentioned book was 'The End of Democracy') stands for more humanistic positions. A nation-state is over, because it is no longer able to satisfy human needs and to solve political tasks. Democracies are no longer sovereign and responsible, as national policy is driven by transnational forces:

"Too remote to manage the problems of our daily life, the nation nevertheless remains too constrained to confront the global problems that affect us. Whether it is a question of the traditional functions of sovereignty, like defense or justice, or of economic competencies, the nation appears increasingly like a straitjacket, poorly adapted to the growing integration of the world (Guéhenno, 1995, pp. 1213).

Actually, the problem of democracy under globalization lies not just in the disappearance of nation-states, but in them losing their exclusive status as the arena of the embodiment of the democratic political and social system. The power as the ability to act, and not as just the dominance, is being decentralized and spread in all multitudes of spheres of human life and activity - from a single family to the global humankind in general. All these spheres naturally intermingle, so that establishing limits of one's 
sovereignty and influence is thankless and an unnecessary task.

What we want to state is that each human person, every developed personality has to become the subject of democracy, obtaining abilities and possibilities to make decisions and to govern his or her own life, and the people ('סńnos') now refer to all the humankind. The problem is that there are not only objective reasons for the new development of democracy (that is, globalization and diminishing powers of nation-states), but subjective reasons as well - the development of human personality that overcomes classical representative democracy.

'L'etat c'est moi', Louis XIV used to say, but today neither President, nor Prime Minister, nor anybody else has moral rights to make such a statement. The state, the society could not be reduced to a unitary nation, or one culture, or a single language. According to our profound conviction, democracy is incompatible with processes of unification - it is possible only as the unity in plurality. The general will of the people could no longer be justifiably represented. Each human personality is the only possible and legitimate representative of his/her own interests, because nobody else has such a unique combination of identities, cultural and biological features. And no politicians could serve as an embodiment of the spirit of the nation. For example, the Orange leaders has appealed for NATO participation, and the western world understood it as an expression of 'Ukraine's' wish to join the Alliance; however, the fact that the majority of the Ukrainian population reject that idea (Atwell, 2008), is often being ignored. Indeed, the people in general are not so eager to follow the path of pseudo-revolutions upheld by élites wanting dominance, as Polish sociologist Jadwiga Staniszkis (2006) demonstrates; masses now are rather pragmatic and pursue their own everyday life, which is quite remote from the 'Big politics' of a nation state.

That is, human persons are able to construct their own democracy, whether we should call it 'neighborhood democracy', grassroots democracy, or ideal democracy of everyone. In order to achieve the real democracy and responsibility, rights of each person must be realized directly, and not through delegates or representatives, like governmental officers or 'professional politicians'. That does not imply that every person must become a politician or a governmental officer. That means that each human person must become a personality as the true driving force of the democratic society.

We believe that we must possess not only rights and opportunities, but also abilities and possibilities as well, in order to function as the subjects of democracy. It is very important to note that such possibilities, as something peculiar to everybody, is not unification and 'leveling' it used to be in some forms of socialism and communism. Indeed, democracy as the unity in plurality supposes cultivating the difference between human beings as its subjects. And the only possible unification here is the same possibility of each person for his or her personal growth, for a creative upbringing of his or her personality.

In order for each person to be able to be different and to develop as a personality, all the people must be equally endorsed not only with political rights, but with social, economical, and cultural rights as well. The political freedom of speech, for example, is a great gain of democracy, but that right alone is surely insufficient for democracy. The freedom of speech remains empty and senseless formality if not based on spiritual and cultural background and filling. Simply speaking, one has something to say, in order to benefit from the given freedom of speech. In other case, that democratic freedom is nothing better than the prohibition of free speech under totalitarian or authoritarian regime. That prohibition at least supposes that a person has some own inherent and intelligent opinion or thought that he/she can express if allowed.

That is, the true democracy could only be enabled by the true personalities. The quality of being the subject of democracy could not be externally imposed on such a personality. You cannot force human to obtain social and political power, to say nothing of the ability and desire to govern. That's why democracy 
could not be organized as any other kind of social system and government. Democracy could only appear as a result of selforganization of human personalities.

It is quite important to note what we mean here by self-organization. It is not selforganization of a system, even it is a social system, as in Niklas Luhmann's theory. It is self-organization of the humans themselves. And what we just said on democracy is true for self-organization as well: there could be no self-organization 'forced' by an inanimate system on living individuals as its 'elements'. Humans are not molecules to be seen from the 'above' with the microscope. Humans are not Bénard's cells that have to self-organize volens-nolens, because the mighty observer (read: the Orange President, the US agency for promoting freedom and democracy, etc.) heats them on a frying pan. Indeed, humans have their own immanent goals, and that's why they do have self-development, selfrealization, and not just self-organization. 'Self' here is just the human self - as in 'selfdiscipline', 'self-critics' - meaning personal ability to be a subject of one's own life. From our point of view, self-organization of a social system is the process of self-development and self-motion of the society in accordance to self-development of humans in that society. In other case, the term 'self-organization' would only designate some outer and inessential form of social development, and not its real essence (Myelkov, 2006).

That's where a non-linear approach to philosophical comprehension of social and political sphere of human life comes into focus again. Both state and society under current stage of a democratization process must be considered according to the methodology of self-organization. More simply, each human is to be comprehended as not means for the state's activity and functioning, but as the goal of such an activity. More precisely, not as an object of influence for achieving let the most optimal forms of social order, but as the subject of the goal-making itself, who is responsible for the development of his or her society towards realizing those goals, who directly performs that realization by his or her own life activity. And it is the personality that serves as the notion describing human being in his or her ability to appear as the subject of goals and values.

The personality itself from the philosophical point of view is the essential force of human, the already mentioned ability to act in a creative way and to be the subject of life and the life of the own society. The personality is the process of development of one's higher self; it is the ideal, and not some external or transcendent ideal, but the immanent ideal that resides within oneself personally. Of course, we must note that each person can be and is engaged in personal and social development: each person could be considered as personality in development, and not just some 'leaders' or 'best people' out of the total population of humanity.

At the same time, personality is not only infinite uniqueness of each human; it also unites him or her with other human beings. The personality, in difference from the individuality, is not something singular; it is rather a mediating link between singular and general. Or, it is such singular that bears the universal in itself. The personality is deeply tied to other personalities, and that tie is not something outer or something casual for that personality, it is presupposed by the personality and forms indispensable condition of his/her own independent existence. Such coherence of personalities is based on their solidarity as for mutual cultural traditions and values that unite them and provide them with the sense of the mutual trust. Trust, inner moral interrelation of personalities enabling their free cooperation in the process of social self-organization, is possible only on the foundation of values, and cannot originate out of any outside compulsion (Tolstoukhov \& Myelkov, 2005).

While based on cultural values, the personality demonstrates a creative approach, creative active relation to those values, their reflection-alteration as the inner contradiction of the personality serving as the source of its self-motion and self-development - and social self-organization as well. Any personalistic practical action appears as a creative transformation of some outer object, as well as that personality itself - either it is a production of the new, or transformation of the old in accordance with current conditions of 
the environment. While mastering the cultural experience of the humanity, the personality recreates that experience, introducing its own, unique dimension into the culture.

Democracy as the self-organization of human personalities does not appear out of nothing. As any development, selforganization is possible on a certain ground, out of some basis only. And in social and personalistic development there is the cultural background that presets possible contexts of senses for that development, presets even certain clusters of options that could be revealed in the process of future selforganization. In other words, only cultural values could enable social development and social organization, providing personalities with all their creative and goal-making abilities.

Traditional cultural values form the eternal foundation for any construction. But eternal here does not mean immutable. On the contrary, every day we create something new, we form new values, on the base of the values that we already possess. The personality appears to be the subject of democracy as social self-organization just because it undergoes its own development towards optimal states, while facing the inner contradiction of preserving/changing its cultural background, its goals and values that set the personality (and its society) into that motion and development.

One can argue that democracy, especially in our global age, could only be presented as the result of collective, and not individual, behavior. It may sound banal, but the development of the personality is inseparable from the development of its community. That is, the personality cannot act and even exist without communities and without other humans, and community is surely nothing without its members. Any collective is composed of individuals, and thus their activities as for social self-organization process cannot be opposed to each other.

However, the collective organization of personalities can obtain different forms in society. Some of these forms enable selforganization of personalities and the development of democracy, others do not. We think that crowd, which so often appears now as a subject of social development (Moscovici, 1991), could not be considered as a community composed of developing personalities. That is, actions of a crowd do not present any kind of democracy and/or social self-organization. A crowd, in its principal difference from any true community, is not an integral group that can justifiably speak and act in the name of its members or even in its own name as some other subject or meta-subject. A crowd is but a chance gathering of people, who cannot, while being in crowd, neither act in a creative way, nor take any responsibility for their actions. Indeed, the crowd could be easily convinced to obey the power of the demagogues, serving as a blind tool in their hands, thus presenting that aspect of organization that opposes it to self-organization of people as the bearers and the conductors of power. Our Lord was crucified by the unanimous decision of a crowd, but such decisions neither reflect the will of all the people, nor could they be presented as just deeds committed for the sake of the common good or social order.

The society or its community is the collective of the people closely united by mutual life, mutual interests, and mutual values. A crowd is not such a collective. Its members are united only by some slogan or some minute impulse with no value and no long-term development orientations behind it. A crowd is not made of free and creative personalities, it could not consolidate people in a real way, and it is not a vital part of the social structure. A person as a part of a crowd appears as an object of external impact, as means for reaching some other goal that is not his or her immanent, but is imposed by somebody else - and not the subject of democracy he or she can and should be.

\section{Conclusion}

Thus, we can outline some conclusion of this article that can serve, in our opinion, as preliminary ideas for the democratization of our society, although the theme of investigating philosophical foundations for democracy is deep enough to host more and more generations of philosophers. Recent uprisings in Eastern Europe, like 'the Orange revolution' in Ukraine in 2004, demonstrate 
the urge to develop our ideas of democracy, so that they would correspond to the current global situation. A nation-state with its unitary and administrative approach - understanding democracy as a representative one, and power as the national governance - is becoming obsolete. Democracy as the unity in plurality cannot be adequately expressed in formulas or social structures possible and effective in all places and under all circumstances. Democracy is not a given state of affairs; instead, it is a non-linear process of social development towards better society where real human beings are bearers and conductors of social and political power. In that sense, no society could yet serve as 'the complete example' of the true democracy. The latter could be considered as a selforganization of society composed of free and conscious human personalities: it is the personality that serves as both the supreme value and the subject of democracy. Both concepts of the people ('סńnos') and power ('кра́тоร') are being developed and concretized, enhancing and augmenting our experience and our striving for a better human society. 


\section{References}

Atwell, K. (2008). Why Ukrainians don't want NATO. Retrieved April 28, 2009, from http://atlanticreview.org/archives/1215Why-Ukrainians-dont-want-NATO.html

Barber, B. (1984). Strong Democracy: Participatory Politics for a New Age. Berkeley/Los Angeles/London: University of California Press.

Crouch, C. (2004). Post-Democracy. Cambridge: Polity Press.

Guéhenno, J.-M. (1995). The End of the Nation-State. Minneapolis: University of Minnesota Press.

Jauvert, V. (2005). Les faiseurs de revolutions. Le Nouvel Observateur, 2116 (26/05/2005), 3-8.

Kushnaryov, Ye. P. (2005). The Red Horse. Notes by the Counterrevolutionary. Kharkov: Kharkov Editions. (In Russian)

Kuzio, T. (2005). From Kuchma to Yushchenko - Ukraine's 2004 presidential elections and the Orange Revolution. Problems of Post-Communism, 52(2), 29-44.

Lifshitz, M. A. (1988). The Moral Meaning of the October Revolution. In M. A. Lifshitz (Ed.), Coll. Works: in 3 vol., Vol. 3 (pp. 230-258). Moscow: Iskusstvo. (In Russian)

Macpherson, C. B. (1973). Democratic Theory: Essays in Retrieval. Oxford: Clarendon Press.

Moscovici, S. (1991). L'âge des foules. Un traité historique de psychologie des masses. Bruxelles: Complexe.

Myelkov, Yu. A. (2006). Personality as the Subject of Social Self-organization. In V. Yevtuh \& I. Dobronravova (Eds.), Cultural Context of Social Self-Organization (pp. 72-82). Kiev: Kiev University Publishing Center

Myelkov, Yu. A. (2007). Democracy and Rationality. Practical Philosophy, 3, 98-109. (In Ukrainian)

Ohmae, K. (1995). The End of the Nation State: The Rise of Regional Economies. New York: Free Press.

Pohrebinskiy, M. B. (Ed.) (2005), “Orange Revolution”: Versions, Chronicle, Documents. Kiev: Optima. (In Russian)

Pohrebinskiy, M. B., Tolpygo A. K. (Eds.) (2007). Ukraine without Kuchma. The Year of the Orange Power. January 2005 March 2006. Kiev: Optima. (In Russian)

Popkin, S. L. (1994). The Reasoning Voter: Communication and Persuasion in Presidential Campaigns. Chicago/London: The University of Chicago Press.

Popova, I. M. (2008). Publicity of Sociology. Sociology: Theory, Methods, Marketing, 2, 14-20. (In Ukrainian)

Richter, P. (2004). We Cannot Accept' Ukraine Vote Results, Powell Says. Los Angeles Times, Nov. 25, 2004, A-18.

Staniszkis, J. (2006). Revolutionäre Eliten, pragmatische Massen: Der Pyrrhussieg der polnischen Populisten. Osteuropa, 11/12, 7-13.

Tolstoukhov, A. V., Myelkov, Yu. A. (2005). Anti-Fukuyama, or Democracy, Trust, and Cultural Values. Practical Philosophy, 2, 3-14. (In Russian)

Tolstoukhov, A. V., Parapan, I. G., \& Myelkov, Yu. A. (2008). Democracy: Power, People, Nation. Practical Philosophy, 4, 69-81. (In Russian)

\section{About the Authors}

Anatoliy Tolstoukhov

Anatoliy Tolstoukhov is the President of the Charity Organization "Center for Practical Philosophy", holds a D.Sc. degree in Philosophy (2004) and a Ph.D. in Philosophy (1999) (both Kiev Shevchenko National University). His major fields of interest are philosophy of ecology, philosophy of politics, and philosophy of science. Anatoliy Tolstoukhov also works as a politician, and currently serves as a member of Ukraine's Parliament.

Yuriy Myelkov

Yuriy Myelkov is the Projects' coordinator at the Charity Organization "Center for Practical Philosophy", holds a Ph.D. in philosophy (2003, Kiev Shevchenko National University). Yuriy's research is focused on philosophical problems of contemporary science, philosophy of nature, and philosophy of democracy. 